\title{
The Contribution of L1 Phonemic Awareness into L2 Reading: The Case of Arab EFL Readers
}

\author{
Yousef Alshaboul $^{1}$, Sahail Asassfeh ${ }^{1}$, Sabri Alshboul ${ }^{2} \&$ Talal Alodwan ${ }^{3}$ \\ ${ }^{1}$ College of Education \& College of Art, Hashemite University, Zarqa, Jordan \\ ${ }^{2}$ College of Art, Hashemite University, Zarqa, Jordan \\ ${ }^{3}$ College of Art \& Human Sciences, The World Islamic Sciences \& Education University, Amman, Jordan \\ Correspondence: Yousef Alshaboul, College of Education and College of Art, Hashemite University, Jordan. Tel: \\ 962-5390-3333. E-mail: yshbool@hu.edu.jo
}

Received: January 14, 2014 Accepted: February 18, 2014 Online Published: February 26, 2014

doi:10.5539/ies.v7n3p99

URL: http://dx.doi.org/10.5539/ies.v7n3p99

\begin{abstract}
Cross-language transfer is the extent, if any, to which phonological awareness in L1 facilitates learning to read in L2. This has been an area of investigation wherein researchers looked into the orthographic and phonological component processing skills L2 learners develop and utilize to facilitate word recognition. Given the difference between the orthographic systems of Arabic (L1) and English (L2), how difficult is it for beginning Arab EFL learners to develop these skills? Arab EFL learners seem to have difficulty with prelexical word recognition processes leading to slower and perhaps even less accurate L2 word recognition skills. This study examines the possibility of transferring Arabic phonological awareness to learning English. Results are reported, most important of which is the confirmation of cross-language transfer.
\end{abstract}

Keywords: phonics, phonemic awareness, phonological awareness, language learners

\section{Introduction}

In spite of being around for years, only recently has phonological awareness won researchers' attention. In their discussion targeting reading difficulties and possible contributing factors, researchers in psychology have focused their attention on the relationship between sound awareness and learners' ability to read (Ehri, 1997; Goswami, 2000; Olofsson \& Niedersoe, 1999). Major conclusions label children who fail to segment or blend spoken words as disabled. The National Reading Panel Report to the U.S. Congress (1998) could not help but to firmly advocate helping children hear sounds in words, know the letters of the alphabet, know letter-to-sound correspondences, and develop the ability to read words (Snow, Burns, \& Griffin, 1998, p. 5, cited in Gillet, Temple, \& Crawford, 2004).

Phonological awareness is defined as the consciousness of (Gillet et al., 2004; Layton, Deeny, Upton, \& Tall, 1988; Stanovich, 1991) and the ability to manipulate (Anthony \& Francis, 2005; Chard \& Dickson, 1999) the language sounds including syllables, onsets and rimes, and phonemes. According to Anthony and Francis (2005), it involves the movement from the recognition of properties to the ability to produce examples. Thus, at one level one can nominate pairs of words that rhyme when presented orally; at a higher level one can produce examples. As they grow older, children develop more and more sensitivity to smaller and smaller word parts; they manipulate syllables before onsets and rimes, manipulate onsets and rimes before individual phonemes, and blend phonological information before they segment.

Research findings confirm that individuals with difficulty in detecting or manipulating sounds in words will struggle with learning to read (see Vellutino, Fletcher, Snowling, \& Scanlon, 2004; Hatcher, Hulme, \& Snowling, 2004; Share, 1995; Snowling, 1998; Anthony \& Farncis, 2005). Accordingly, a legitimate association between phonological awareness and reading development is possible.

\section{Area Description}

To date, Arabic phonological awareness has not received its due attention (Alshaboul, Asassfeh, Alshboul, \& Momani, 2013) let alone the possibility of using this awareness in EFL learning experiences. This study, which investigates the effect of Arabic phonological awareness (L1) on learning English (L2), is a step towards filling 
this void.

At the outset, Arabic utilizes an alphabetic orthography that corresponds to consonant and vowel phonemes (Fender, 2003). The Arabic orthographic system is phonologically transparent (Wanger, 1993; Abu-Rabia, 1997a, 1999), which should facilitate Arab learners' L1 word recognition (Abu-Rabia, 1997b). English orthography, on the other hand is less phonologically transparent (Fender, 2003); it has many inconsistencies regarding both the orthographic representation of vowels and the variety of context-sensitive phoneme-grapheme irregularities (For further detail see Berent \& Perfetti, 1995; Cortese \& Simpson, 2000). Thus, fluent readers of English need to develop orthographic and phonological processing skills to facilitate word recognition (Gough \& Walsh, 1991; Perfetti, 1991; Seidenberg, 1992; Stanovich, 1991). Given these demands and the possibility of L1 interference, Arab learners of English may encounter extra burden and more challenges.

When reading the words in the target language, Finder (2003) assumes that Arab students would rely on phonological processing skills developed through L1 literacy experience; this will result in "slower and perhaps even less accurate ESL word recognition skills" (p. 294). Brown and Hyness (1985) and Ryan and Meara (1991) support this stance claiming that Arab EFL learners may experience different types of difficulties at the world level while reading English texts. Back to Fender (2003), Arab EFL learners face difficulties identifying the printed form of a word needed to activate pragmatic associations. Such processes operate at a prelexical stage and are necessary to identify and activate a word or a lexical item (Siedenberg, 1992; Stanovich, 1991; Vellutino, Scanlon, \& Tanzman, 1994). Knowledge of these processes is deemed crucial for second language reading fluency and comprehension (Perfetti, 1985; Eskey, 1988; MacDonald, 2000).

This line of research is supported by the work of Bruck and Genesee (1995), Campbell and Sais (1995), and Rubin and Turner (1989) who compared phonological awareness skills in bilingual and monolingual children. Such studies predicted that young children exposed to more than one language would perform better on phonological awareness tasks than monolingual peers. In Rubin and Turner's study, sixteen Canadian English-speaking first graders attending French immersion programs showed higher proficiency in analyzing the internal syllabic and phonemic structure of orally presented words than the sixteen who attended English-medium programs. In their study, Bruck and Genesee (1995) examined phonological awareness skills at different levels (syllable, onset-rime and phoneme) longitudinally on a similar Canadian population. They found some evidence for superior performance at syllable and onset-rime level (the latter limited to kindergarten children) for the bilingual children. The bilingual advantage at the syllable level is attributed to the extra saliency of the syllable in French, which allows earlier awareness of syllables to transfer to English. The monolingual first-grade English children showed superior performance at the phoneme level due to their learning to read and write in English, as suggested by Bruck and Genesee (1995). The Campbell and Sais study compared the phonological awareness skills of fifteen four-year old monolingual English-speaking children to the skills of fifteen age-matched English speakers with varying degrees of exposure to Italian. Again the bilingual group demonstrated superior performance. This superiority, it is suggested, depends on the fact that Italian has a more regular syllabic and phonological structure than English, facilitating the development of phonological awareness.

\subsection{Cross-Language Transfer}

Cross-language transfer is the extent to which phonological awareness in the first language facilitates learning to read in the second language. This is an important area of research interested in bilingual children's phonological awareness. Researchers faced challenge in their trials to identify causes of reading difficulties; Durgunoglu (2002) assumed that "cross-language transfer" entails that language learners can transfer their skills in L1 to learn L2.

In previous research, Durgunoglu et al. (1993) examined the relationship between phonemic awareness in Spanish and word reading in English. Good performance on three phoneme awareness tasks (involving segmentation, blending and matching) given in Spanish was associated with better ability to read English words and pseudo-words. Later in 1998 Durgunog lu carried out another study on forty-six Spanish-speaking children attending Grade 1 tested on a variety of tasks given in both languages. Performance on Spanish and English phonological awareness tasks was significantly correlated. This permits the inference that metalinguistic awareness of one language transfers to the second, facilitating L2 reading development. This stance was supported by Comeau, Cormier, Grandmaison, and Lacroix (1999) who confirmed that phonological awareness in English was strongly related to reading achievement in French, and vice versa.

Notably, all these studies were carried out on languages with similar alphabetic scripts where phonological awareness is highly correlated. Orthographic complexity differs from one language to another, which directly impacts the consistency between phoneme-grapheme correspondences. In cases where a grapheme represents the 
same phoneme and a phoneme represents the same grapheme consistently, the orthography can be labeled as transparent or shallow.

On the other hand, there are inconsistent or deep correspondences between phonemes and graphemes. English is a good example since it is described as polyphonic and polygraphic. Languages such as English contain more challenges for learners especially if their mother tongues are shallower. Hence, this study is significant due to the fact that it investigates two languages that differ drastically in their alphabetic script- Arabic and English.

Arabic is an alphabetic language that consists of 28 letters. Arabic writing goes from right to left, which is completely the opposite of English. Arabic language has three long vowels represented by $/ \mathrm{i} /, / \mathrm{u} / \mathrm{and} / \mathrm{a} /$, and three short ones represented by diacritics. Arabic has a regular grapheme-to-phoneme and phoneme-to-grapheme correspondences (Abu-Rabia, 1997a; Wagner, 1993). With Arabic described as transparent and English as less phonologically transparent or deep, will this discrepancy in the orthographic system affect learning English as a foreign language?

There are studies, yet very few that show the phonological skills of the mother language contributing to the development of the skills in the second or foreign language (Chikamatsu, 1996; Cisero \& Royer, 1995; Durgunoglu, Nagy, \& Hancin-Bhatt, 1993; Green, 1997; Holm \& Dodd, 1996; Koda, 1990). According to Wagner, Spratt, \& Ezzaki (1989), phonological awareness can transfer between the mother language and the second language even if the two languages do not share the same orthographic system, like Arabic and French. This line of research gains much support from Cummins' $(1981,1989)$ interdependence and threshold hypotheses. Cummins suggests that the proficiency in one language successfully transfers cross languages when learning new tongues. Fashola, Drum, Mayer, and Kang (1996) confirmed the cross-language transfer and showed that bilingual children may rely on their phonological awareness of L1 to learn new language. Verhoeven's (1994) findings confirmed the principle of transferring L1 knowledge to learning L2.

Following His Majesty King Abdullah II's 1999 National Initiative, the Ministry of Education in Jordan started teaching English as mandatory right from the first grade in order to enable Jordanian first graders to obtain command on English basic skills. The English Language National Team, 2006, expected first graders to "read English from left to right and show understanding of learned simple words about names, objects, actions, and numbers when reading through different activities." This study, in turn examined the possibility of using the phonological awareness of Arabic language to facilitate learning English.

\subsection{Questions of the Study}

Given the differences in regard to phonological transparency, shallow vs. deep, for Arabic and English respectively, this study came to answer the following two questions: do Arabic phonological awareness skills and insights help Jordanian students read English better? If yes, can that be attributed to cross-language transfer?

\section{Method}

\subsection{Participants}

The participants of the study were 35 (20 boys and 15 girls) Jordanian first-graders with an average age of 6:10. All native speakers of Arabic, they were just exposed to English as a foreign language. According to their teachers' evaluation, those students were beginning readers. All participants took the tests in April and May, 2012.

\subsection{Instruments}

\subsubsection{Letter Identification}

In order to determine the number of letters a student could correctly identify, Clay's (1979) letter identification test was used. The test included 26 uppercase and 28 lowercase letters, making 54 the highest possible earned score. When the child could give either the name or the sound of the letter in either Arabic or English, it was counted as correct.

\subsubsection{English Word Recognition}

In order to determine how many words the child could read in English, Clay's (1979) Ready-to-Read Word Test (List C) was used. The test contained fifteen common English words. The Experimenters gave explicit instructions telling the participants that they were about to read English words. The experimenter started by reading the for-practice words on the top of the list and then asked the participants to read the remaining of the fifteen words. The participants were credited one point for each word read correctly. 


\subsubsection{Arabic Word Recognition}

Since there were no standardized reading tests in Arabic, the researchers developed a test based on the Arabic vocabulary used in the school textbooks in Jordan (Alshaboul et al, 2013). This approach has been used in previous cross-linguistic research when no standardized tests exist (Baluch \& Shahidi, 1991; Bruck, Geneseea, \& Caravolas, 1997; Arab-Moghaddam \& Senechal, 2001). The test consisted of fifteen common Arabic words used to assess the participants' reading ability. The same procedures were followed in the English word list.

\subsection{Arabic Phonological Awareness Test}

In order to test the Arabic phonological awareness, a test including segmenting, blending, and matching was developed. The researchers and experimenters gave materials to and did some exercise practices with the participants in Arabic prior to the tests in order to make sure that the students understood the task. Each participant received feedback from the experimenter during the practice. If the participant did not provide any answer, or if the answer was incorrect, the experimenter gave the correct answer. The researchers and experimenters gave test instructions in Arabic. The number of correct responses on each exercise formed the student's total score.

\subsubsection{Segmenting Task}

This task aimed at assessing the student's ability to divide Arabic words into phonemes, syllables, and onset-rime units. The Experimenter told the participants that they would divide words into small parts through playing with words. The experimenter did an exercise to show the students how to divide the word. Three subsections were included; (a) 8 two-phoneme words segmented into their two phonemes, (b) 4 two-phoneme words segmented into their two syllables, and 8 three-phoneme words segmented into their three phonemes. The highest score was 20 with one point for each correct response.

\subsubsection{Blending Task}

The aim of this task was to determine the participants' ability to blend isolated sounds into words. The experimenter gave the parts of words, and the participants had to put the parts together to sound out the words. The blending task consisted of three subsections; (a) 6 three-phoneme words given as two syllables, (b) 6 three-phoneme words given as onset-rimes, and (c) 8 three-phoneme words given as phonemes. Participants were credited one point for each correct response. The total score on this task was 20.

\subsubsection{Matching Task}

This task aimed at determining each participant's ability to match the initial sounds in words. The experimenter gave a target word and three alternatives; the participant, and after listening to the target words, had to choose the right word that contains the right answer from the alternatives. In each trial the experimenter instructed the participants to listen to certain sounds at the beginning of a group of words. The matching task included (a) 6 words matched in terms of initial phoneme in a broken syllable, (b) 8 words matched in terms of initial two phonemes in an intact syllable, and (c) 6 words matched in terms of the initial two sounds in a broken syllable. Each correct response was credited one point.

\subsection{Transfer Tests}

In order to assess the transference of Arabic phonological awareness to English, the researchers used two tests of word recognition. At first, the participants were instructed how to read several English-like pseudo-words. Later, and on a transfer test, the participants were asked to read a list of words that contained the onsets and rimes of the pseudo-words presented at the beginning. In this part of testing, the experimenters gave instruction all in English.

\subsubsection{Pseudo-Word Reading}

The researchers used eight English-like pseudo-words. The experimenters sounded out the pseudo-words before the training and then asked the participants to segment each pseudo-word as onset-rime unit. The experimenters helped the students in pronouncing the difficult pseudo-words. The participants were told at the beginning that those were not real words. In order to ensure that the participant learned how to read those pseudo-words, the researchers followed Yopp's (1988) procedure. This teach-test procedure continued for a maximum of five trials. Scoring this task was different from the other tasks; it counted the number of correctly read items on each trial of the five multiplied by the corresponding weight to get a score for each trial.

\subsubsection{Word Reading}

The researchers created six words through combining the onset-rime sounds of the pseudo-words studied at the 
beginning. The experimenter put those words on cards and went through them once with the participants sounding and blending. The experimenters shuffled the cards and then gave them to the participants to read. The highest score to obtain was six.

\subsection{Procedures}

The researchers and experimenters, fluent in both Arabic and English, administered all the tasks and tests to each subject individually; each was tested twice with a ten-day interval. During the first round of testing, the researchers and the experimenters administered all the Arabic tests along with the English word recognition test. All instructions were delivered in Arabic. The students were tested in the following: letter identification, English word recognition, and Arabic phonological awareness test respectively. Each session lasted for 45 minutes. Unless a need was perceived to translate into Arabic, instructions in the second round of testing were given in English. The second session included English-like pseudo word training and reading and English word-reading tests. With breaks between the tests, the second round of testing lasted for 35 minutes. All tests were tape-recorded for later transcription.

\section{Results}

To date, this study is the first in the field that examines whether phonological awareness in Arabic can help Jordanian students perform better on the English transfer tasks. All participants were tested using tasks that contain large (syllable, onset and rime) and small phonological units. Literature suggests that phonological awareness, at least at the onset-rime level, predicts success in early reading. Basically, individuals who have difficulty detecting or manipulating sounds in words will struggle with learning to read.

\subsection{Word Recognition and Letter Identification}

Upon running the descriptive analyses for all tests, it was clear that Arabic word recognition $(M=.76, S D=.33)$ was almost twice easier than English word recognition $(M=.36, S D=.30)$. In fact, participants could recognize only one word easily $(M=.74, S D=.43)$ with the next getting a mean as low as $(M=.53, S D=.50)$. The other mean scores were much lower with the least being $(M=.19, S D=.40)$. On the other hand, the participants did better with mean score ranging from $(M=.87, S D=.34)$ to $(M=.68, S D=.46)$.

To see if the mean difference between word recognition in L1 and L2 was significant, paired- sample $t$ - test was used. The results (Table 1) indicated a significant difference $(t=1.19, p<.05)$. Furthermore, English upper-case letters $(M=.16 .56, S D=7.15)$ were easier than English lower-case $(M=.15 .57, S D=7.29)$ with the upper-case $[\mathrm{X}]$ and lower-case [o] being the easiest, scoring mean values of $(M=.91, S D=.28)$ and $(M=.89, S D=.31)$ respectively. By the same token, the following letters, both as uppers and lowers, scored the lowest [v, q, y, u, j].

Table 1. Paired sample test

\begin{tabular}{|c|c|c|c|c|c|c|c|c|}
\hline & & \multicolumn{5}{|c|}{ Paired Differences } & \multirow{3}{*}{$\mathrm{T} \quad \mathrm{Df}$} & \multirow{3}{*}{$\begin{array}{c}\text { Sig. } \\
\text { (2-tailed) }\end{array}$} \\
\hline & & \multirow{2}{*}{ Mean } & \multirow{2}{*}{$\begin{array}{c}\text { Std. } \\
\text { Deviation }\end{array}$} & \multirow{2}{*}{$\begin{array}{l}\text { Std. Error } \\
\text { Mean }\end{array}$} & \multicolumn{2}{|c|}{$\begin{array}{l}\text { 95\% Confidence Interval of the } \\
\text { Difference }\end{array}$} & & \\
\hline & & & & & Lower & Upper & & \\
\hline $\begin{array}{c}\text { Pair } \\
1\end{array}$ & $\begin{array}{l}\text { English } \\
\text { recognition- } \\
\text { Arabic } \\
\text { recognition }\end{array}$ & -4.06 & 3.09 & .03 & -4.73 & -.34 & -1.2082 & .001 \\
\hline
\end{tabular}

\subsection{Phonological Awareness}

In order to test participants' phonological awareness in L1, three tests were used; segmenting, blending, and matching. The reported mean scores ranked blending $(M=7.33, S D=1.05)$ on top, followed by matching $(M=$ $6.22, S D=1.28)$ and, finally, segmenting $(M=5.16, S D=1.34)$.

Upon looking closely within each of those phonological tests and comparing mean score values per each subcategory, results showed that blending phoneme words as phonemes scored on tope followed by phoneme words blended as syllables and phoneme words as onset-rime $(M=7.60, S D=.89 ; M=5.31, S D=1.05 ; M=$ $4.63, S D=1.58)$ respectively. For segmenting, results showed the two-phoneme words segmented into 
phonemes on top, followed by those segmented into three phonemes, and then words segmented into syllables at the bottom $(M=6.78, S D=1.99 ; M=5.17, S D=1.35 ; M=3.55, S D=.99)$ respectively. Concerning the third phonological awareness test, the reported means indicated that matching words on the basis of their two phonemes in intact syllables to be the easiest followed by words matched on the basis of their initial phoneme followed by words matched on basis of initial two sounds $(M=6.91, S D=1.44 ; M=5.10, S D=1.34 ; M=4.85$, $S D=1.37$ ) respectively.

Correlation test was carried out in order to determine the interrelatedness of these three phonological awareness tests. Results (Table 2) indicated that there was an interrelation among the three components of phonological awareness tests; blending and segmenting had higher correlation $(\mathrm{r}=.68)$ than blending and matching $(\mathrm{r}=.56)$. Because the phonological awareness tests were interrelated, that warranted using the total score of these three tests to be used as one measure when referring to the phonological construct in later analysis.

Table 2. Correlation between components of phonological awareness tests correlations

\begin{tabular}{|c|c|c|c|c|}
\hline \multicolumn{5}{|c|}{ Matching Segmenting Blending } \\
\hline \multirow{5}{*}{ Matching } & Pearson Correlation & 1 & .55 & .56 \\
\hline & Sig. (2-tailed) & & .05 & .05 \\
\hline & Sum of Squares and Cross-products & 1024.80 & 580.75 & 442.54 \\
\hline & Covariance & 12.50 & 7.08 & 5.40 \\
\hline & $\mathrm{N}$ & 83 & 83 & 83 \\
\hline \multirow{5}{*}{ Segmenting } & Pearson Correlation & $.55 * *$ & 1 & .68 \\
\hline & Sig. (2-tailed) & .05 & & .05 \\
\hline & Sum of Squares and Cross-products & 580.75 & 1080.28 & 549.96 \\
\hline & Covariance & 7.08 & 13.17 & 6.71 \\
\hline & $\mathrm{N}$ & 83 & 83 & 83 \\
\hline \multirow{5}{*}{ Blending } & Pearson Correlation & .56 & .68 & 1 \\
\hline & Sig. (2-tailed) & .05 & .05 & \\
\hline & Sum of Squares and Cross-products & 442.54 & 549.96 & 608.51 \\
\hline & Covariance & 5.40 & 6.71 & 7.42 \\
\hline & $\mathrm{N}$ & 83 & 83 & 83 \\
\hline
\end{tabular}

Upon analyzing participants' responses on the pseudo word test, the mean score for respondents was relatively low $(M=172, S D=115)$ (Table 3$)$. Sine this study was primarily conducted to investigate the relationship between L1 phonological awareness and reading in L2, the phonological awareness score was correlated with the English pseudo words and the English words reading. Results (Table 4) confirm a significant correlation between these tests: phonological awareness score was found to significantly correlate with the participants' performance on both the pseudo and word reading transfer tests $(r=.27$ and $r=.56)$ respectively with a higher correlation to the benefit of English word reading. 
Table 3. Descriptive statistics for the correlation between PA, word reading, and pseudo words

\begin{tabular}{ccc}
\hline & Mean & Std. Deviation \\
\hline Phonemic awareness & 52.11 & 8.45 \\
English pseudo words & 172.55 & 115.30 \\
English word reading & 3.24 & 2.02 \\
\hline
\end{tabular}

Table 4. Correlation between PA, word reading, and pseudo words correlations

\begin{tabular}{ccccc}
\hline & & $\begin{array}{c}\text { Phonemic } \\
\text { awareness }\end{array}$ & $\begin{array}{c}\text { Pseudo word } \\
\text { reading }\end{array}$ & $\begin{array}{c}\text { English word } \\
\text { reading }\end{array}$ \\
\hline \multirow{3}{*}{ Phonemic awareness } & Pearson Correlation & 1 & $.27^{*}$ & .57 \\
& Sig. (2-tailed) & & .01 & .05 \\
& $\mathrm{~N}$ & 83 & 83 & 83 \\
\hline \multirow{2}{*}{ Pseudo word reading } & Pearson Correlation & $.27^{*}$ & 1 & $.37^{* *}$ \\
& Sig. (2-tailed) & .01 & & .01 \\
& $\mathrm{~N}$ & 83 & 83 & 83 \\
\hline \multirow{3}{*}{ English word reading } & Pearson Correlation & .57 & .37 & 1 \\
& Sig. (2-tailed) & .05 & .01 & 83 \\
\hline
\end{tabular}

*. Correlation is significant at the 0.05 level (2-tailed).

**. Correlation is significant at the 0.01 level (2-tailed).

In order to find out whether Arabic phonological awareness may predict Jordanian students' performance on English reading, multiple-regression analysis was performed with word reading and pseudo word reading being the dependent variables. The independent variables were English word recognition, letter identification, Arabic word recognition, and the sum of Arabic phonological awareness. The four independent variables significantly predicted English word reading; they were responsible for $50 \%$ of the explanation for the variance in word reading $($ Table 5$), F(4,78)=19.77, p<.05$.

Table 5. Regression analysis on English word reading

\begin{tabular}{lcc}
\hline Test Variable & $\mathrm{B}$ & $\mathrm{t}$ \\
\hline (Constant) & -1.35 & -1.16 \\
Arabic word recognition & -.01 & -.14 \\
English word recognition & 157 & 3.20 \\
Phonemic awareness & .05 & 1.68 \\
English letter identification & .04 & 2.04 \\
\hline
\end{tabular}

Concerning the pseudo word reading, regression analysis indicated that phonological awareness accounted for $19 \%$ of the variance, $F(4,78)=4.56, p<.01$ (Table 6 ). 
Table 6. Regression analysis on English pseudo word reading

\begin{tabular}{lcc}
\hline Test Variable & $\mathrm{B}$ & $\mathrm{t}$ \\
\hline (Constant) & 1.11 & .281 \\
Arabic word recognition & .11 & .650 \\
English word recognition & .17 & 1.027 \\
Phonemic awareness & .07 & .663 \\
English letter identification & .06 & .960 \\
\hline
\end{tabular}

\section{Discussion}

This study investigated the relationship between Arabic phonological awareness and English word reading. As literature confirms the positive relationship between phonological awareness and reading, the findings of this study were of special value for investigating two drastically different languages; Arabic, described as transparent (Wanger, 1993; Abu-Rabia, 1997a, 1999), and English, a less phonologically transparent language (Fender, 2003).

As far as Arabic is concerned, a high consistent set of phoneme-grapheme correspondences works on facilitating Arab learners' L1 word recognition developed through phonological processing skills. English, on the other hand, may create problems for Arab EFL learners due to its less phoneme-grapheme consistency. Fender (2003), for example, suggests that English orthography encodes a large amount of phonological information through phoneme-grapheme correspondence rules. English has many inconsistencies with regard to how vowels are represented in the orthography as well as a variety of context-sensitive phoneme-grapheme irregularities. In a nutshell, one might, logically, conclude that language learners targeting a transparent language will presumably face fewer problems than those learning a less transparent language.

This realization is manifest in performance; Jordanian students did better, twice easier, in their mother tongue word recognition than in English word recognition. In fact, their performance on most English word recognition was poor, which indicates clearly the disqualification of The English Language National Team expectations announced in 2006-that Jordanian first graders are to read English words and to show understanding of learned simple words about names, objects, actions, and numbers when reading through different activities. This finding suggests that EFL Jordanian children did not receive efficient instruction addressing new English words. This goes in line with our next result showing that the same students did well on letter identification.

Participants' performance on letter identification was better; they scored high on both upper and lower case letters. Such a result supports more our conclusion that teachers' instructions lend itself more towards letter-focus rather than word-focus. Still, the children did even a little better on the upper case letters rather than the lower case. The visibility, bound to the clearer image, shape, and boundaries of the letters, might be possible reasons. In addition, results showed that the easiest letter to be recognized was the English upper-case [X] followed by the lower-case [o]. A feasible explanation might resort to exposure and simplicity: children encounter the shapes of $[\mathrm{X}]$ and $[\mathrm{o}]$ more often than the rest of the letters; they may also find the letter-drawing easier.

It is worth mentioning that children faced hard time identifying the following group of letters $[v, q, y, u, j]$ in both upper and lower case. A practical explanation might situate itself in familiarity and availability: Arabic language does not have these sounds in its system, so children are not familiar with them. Consequently, Arab children do not see and do not use these letters in their mother tongue. So, they face a problem manipulating and producing these sounds-denoting potential reading difficulties.

Several possibilities may stand behind teachers over emphasis on letters rather than words. First, old-hand teachers prefer to resort to traditional approaches they inherited from their schooling experience: an attachment to the past that makes them feel more secure with what they are familiar with (Asassfeh et al., 2012). Second, novice teachers are not at a better stand. They enter the classroom without having any sort of prior preparation, an impediment that has surfaced as a nation-wide problem since the cancelation of the field-teacher programs a decade ago. Third, some might assume that those children are in more need for letters, instead of words, in order to become better readers - a practice grounds itself in phonics.

Consequently, much work is needed to validate this finding and, of no less importance, to ensure that Jordanian EFL children will not be left behind and will not suffer later, unnecessarily, in learning English. Prudently, there 
is a need for direct instruction and classroom activities to target the word as a whole not just as letters-leaving the early EFL learner spending most of the reading time on just decoding. This calls for qualified and dedicated teachers who ground themselves well in what teaching is and what teaching means. Such a result suggests the need for efficient instruction based on thoughtful and early assessment in order to identify areas of strengths and weaknesses and level the ground for those children to become better readers.

Replicating results hosted in literature, it was noted that all of the three phonological awareness tests were interrelated with the highest correlation between blending and segmenting-entitling the researchers to use one score to represent the three phonological tests in later tests. Back to the tests, participants performed best on blending followed by matching and then segmenting - a result that confirmed what Anthony and Francis (2005) suggested when indicating that children attend blending before segmenting. This could be considered normal emergence into literacy when matched up with the right stage of age. Classroom teachers being the closest to the children need to be so attentive and to bring more balance to the phonological components, so that EFL learners emerge competent and skillful in all of them instead of having a limp in one or more leading to a slower reader.

A remarkable and a unique result was the EFL learners' performance on the subtests within each of the three phonological awareness tests. For example, blending phoneme words as phonemes was the easiest followed by phoneme words blended as syllables and onset-rimes. Same pattern repeated itself in segmenting-a result that sounded contradictory to what literature indicates. Anthony and Francis (2005) suggest that children become increasingly sensitive to smaller and smaller parts of words as they grow older, a sequence that did not sell itself to Arabic native speakers but proved more salient to English speakers. An explanation to this does not divorce itself from a previously mentioned argument that relates Arabic speakers' focus on discrete letters to teachers' practices and instructions. A left print for this result suggests more focus on manipulating syllables and onset-rime.

To end with, the momentous result touched on the possibility of Arabic (L1) phonological awareness to cross to reading English (L2) pronouncing a positive transfer. This could have been interpreted in two ways. First, phonological awareness was found to significantly correlate with the participants' reading performance on English both the pseudo and word reading. This suggests that the power of phonological awareness may predict students' performance on word reading. Second, same result clearly shows Arabic EFL children to suffer twice more when reading English pseudo words than English words. This language ability to identify the printed form in order to activate the semantic, syntactic, and pragmatic associations was deemed necessary for L2 learners to achieve reading fluency and comprehension (Eskey, 1988; Fender, 2003; MacDonald, 2000; Perfetti, 1985; Siedenberg, 1992; Stanovich, 1991; Vellutino, Scanlon, \& Tanzman, 1994). This conclusion was verified with phonological awareness in L1 being responsible for just $19 \%$ of pseudo word reading, while it was responsible for 50\% in reading English words. In summary, children who perform well on Arabic phonological awareness are more likely to become better English readers-a result that can revolutionize the teaching-learning process of English in its Arabic EFL context.

Revisiting the previously announced importance of the study for examining two drastically different languages, one cannot help but to concur on these results in order to revise, develop, and engineer the right environment for language learning. Every stakeholder is responsible for making valuable contributions in order to facilitate the experience of the Jordanian children when learning English. Instructors may use children's Arabic as a source-of-power to support their learning English. Teachers, care givers, and immediate adults should not neglect the importance of learners' strength points in L1 to learn L2. This may warrant the following conclusion: a child poor performance on L2 might be due to poor performance on L1 phonological awareness. What intervention this conclusion invites constitutes an avenue that deserves more research and investigation.

\section{References}

Abu-Rabia, S. (1997a). Reading in Arabic Orthography: The effect of vowels and context on reading accuracy of poor and skilled native Arabic readers in reading paragraphs, sentences, and isolated words. Journal of psycholinguistic Research, 26, 465-482. http://dx.doi.org/10.1023/A:1025034220924

Abu-Rabia, S. (1997b). Reading in Arabic orthography: The effect of vowels and context on reading accuracy of poor and skilled native Arabic readers. Reading and Writing: An interdisciplinary Journal, 9, 65-78.

Abu-Rabia, S. (1999). The effect of Arabic vowels on the reading comprehension of second-and sixth-grade native Arab children. Journal of Psycholinguistic Research, 28, 39-101.

Adams, M. (1990). Beginning to read: Thinking and learning about the print. Cambridge, MA: MIT Press.

Al-Shaboul, Y., Asassfeh, S., Alshboul, S., \& Momani. (2013). Are Jordanian students phonemically aware? A 
descriptive study. Journal of Educational and Psychological Sciences, 14(2), 37-53.

Anthony, J., Lonigan, C., Driscoll, K., Phillips, B., \& Burgess, S. (2003). Phonological Sensitivity: A quasi-parallel progression of word structure units and cognitive operations. Reading Research Quarterly, 38, 470-487. http://dx.doi.org/10.1598/RRQ.38.4.3

Anthony, L., \& Francis, D. (2005). Development of Phonological Awareness. American Psychological Society, 14(5), 255-258.

Arab-Moghadam, N., \& Senechal, M. (2001). Orthographic and phonological processing skills in reading and spelling in Persian/English bilingual. International Journal of Behavioral Development, 25, 140-147. http://dx.doi.org/10.1080/01650250042000320

Asassfeh, S., Alshaboul, Y., \& Alodwan, T. (2012). In-Service EFL Teachers' Views of Form-Focused Instruction (FFI) and Communicative Meaning-Oriented Instruction (MOI): The Case of Jordan. European Journal of Social Sciences, 30(1), 78-91.

Baluch, B., \& Shahidi, S. (1991). Visual word recognition in beginning readers of Persian. Perceptual and Motor Skills, 72, 1327-1331. http://dx.doi.org/10.2466/pms.1991.72.3c.1327

Berent, I., \& Perfetti, C. (1995). A rose is a REEZ: The two-cycles model of phonology assembly in reading English. Psychological Review, 102, 146-184. http://dx.doi.org/10.1037/0033-295X.102.1.146

Blachman, B. (1991). Early intervention for children's reading problems: Clinical applications of the research in phonological awareness. Topics in Language Disorders, 12, 51-65. http://dx.doi.org/10.1097/00011363-199112010-00006

Blachman, B. (2000). Phonological awareness. In M. L. Kamil, P. B. Mosenthal, P. D. Pearson, \& R. Barr (Eds.), Handbook of Reading Research (Vol. III). Lawrence Erlbaum, New Jersey.

Blanchman, B. (2000). An Overview of the STARS Program. Syracuse, NY: Syracuse University School of Education: Syracuse Reading Project.

Brown, T. L., \& Haynes, M. (1985). Literacy background and reading development in a second language. In T. H. Carr (Ed.), The development of reading skills. San Francisco, CA: Jossey-Bass.

Bruck, M., \& Geneseea, F. (1995). Phonological awareness in young second language learners. Journal of Child Language, 22, 307-324. http://dx.doi.org/10.1017/S0305000900009806

Bruck, M., Geneseea, F., \& Caravolas, M. (1997). A cross-linguistic study of early literacy acquisition. In B. Blachman (Ed.), Foundation of reading acquisition and dyslexia (pp. 145-162). Hillsdale, NJ: Erlbaum.

Campbell, R., \& Sais, E. (1995). Accelerated metalinguistic (phonological) awareness in bilingual children. British Journal of Developmental Psychology, $13, \quad 61-68$. http://dx.doi.org/10.1111/j.2044-835X.1995.tb00664.x

Chard, D., \& Dickson, S. (1999). Phonological awareness: Instructional and assessment guidelines. Intervention in School and Clinic, 34, 261-270. http://dx.doi.org/10.1177/105345129903400502

Chera, P. (2000). Multimedia CAL and early reading: Iterative design, development and evaluation (Unpublished PhD thesis, University of Bristol, UK).

Chera, P., \& Wood, C. (2003). Animated Multimedia "taking books" can promote phonological awareness in children beginning to read. Learning and instruction, 13, 33-52. http://dx.doi.org/10.1016/S0959-4752(01)00035-4

Chikamatsu, N. (1996). The effects of L1 orthography on L2 word recognition: A study of American and Chinese learners of Japanese. Studies in Second Language Acquisition, 18(4), 403-432. http://dx.doi.org/10.1017/S0272263100015369

Cisero, C. A., \& Royer, J. M. (1995). The development and cross-language transfer of phonological awareness. Contemporary Educational Psychology, 20, 275-303. http://dx.doi.org/10.1006/ceps.1995.1018

Clay, M. (1979). The early detection of reading difficulties (3rd ed.). Portsmouth, NH: Heinemann.

Comeau, L., Cormier, P., Grandmaison, E., \& Lacroix, D. (1999). A longitudinal study of phonological processing skills in children learning to read in a second language. Journal of Educational Psychology, 91, 29-43. http://dx.doi.org/10.1037/0022-0663.91.1.29

Cortese, M., \& Simpson, G. (2000). Regularity effects in word naming: What are they? Memory and Cognition, 


\section{8, 1269-1276. http://dx.doi.org/10.3758/BF03211827}

Cummins, J. (1981). The role of primary language development in promoting educational success for language minority students. In Schooling and language minority students (pp. 3-49). Sacramento, CA: California Department of Education.

Cummins, J. (1989). Empowering minority students. Sacramento, CA: California Association for Bilingual Education.

Durgunoglu, A. (1998). Acquiring literacy in English and Spanish in the United States. In A. Y. Durgunoglu, \& L. Verhoeven (Eds.), Literacy development in a multilingual context: Cross-cultural perspectives (pp. 135-146). Mahwah, NJ: Erlbaum and Associates.

Durgunoglu, A., Nagy, W., \& Hancin-Bhatt, B. (1993). Cross-language transfer of phonological awareness. Journal of Educational Psychology, 85, 453-465. http://dx.doi.org/10.1037/0022-0663.85.3.453

Ehri, L. (1991). Development of the ability to read words. In R. Kamil, P. Mosenthal, \& P. Pearson (Eds.), Handbook of reading (Vol. 2). New York: Longman.

Eskey, D. (1988). Holding in the bottom: An interactive approach to the language problems of second language readers. In P. Carrell, J. Devine, \& D. Eskey (Eds.), Interactive approaches to second language reading. New York: Cambridge University Press. http://dx.doi.org/10.1017/CBO9781139524513.011

Fashola, O. S., Drum, P. A., Mayer, R. E., \& Kang, S. J. (1996). A cognitive theory of orthographic transitioning: Predictable errors in how Spanish-speaking children spell English words. American Educational Research Journal, 33, 825-843. http://dx.doi.org/10.3102/00028312033004825

Fender, M. (2003). English word recognition and word integration skills of native Arabic and Japanese- speaking learners of English as a second language. Applied Psycholinguistics, 24, 289-315. http://dx.doi.org/10.1017/S014271640300016X

Gillet, J., Temple, C., \& Crawford, A. (2004). Understanding Reading Problems: Assessment and Instruction. Boston: Allyn and Bacon.

Goswami, U., \& Brynant, P. (1990). Phonological skills and Learning to Read. Lawrence Erlbaum, Hove.

Goswami, U. (1994). The role of analogies in reading development. In C. Gains, \& D. Wray (Eds.), Reading: Issues and Directions. Stafford: NASEN Enterprises Ltd.

Goswami, U. (2000). Phonological and lexical processes. In M. Kamil, P. Mosenthal, P. Pearson, \& R. Barr, (Eds.), Handbook of Reading Research (Vol. III). Mahwah, NJ: Lawrence Erlbaum.

Goswami, U. (2000). Phonological representations, reading development and dyslexia: Towards a $\begin{array}{lllll}\text { cross-linguistic theoretical } \quad \text { framework. } & \text { Dyslexia, } & 6, & 133-151 .\end{array}$ http://dx.doi.org/10.1002/(SICI)1099-0909(200004/06)6:2<133::AID-DYS160>3.0.CO;2-A

Gough, P., \& Walsh, M. (1991). Chinese, Phoneticians, and the orthographic cipher of English. In S. Brady, \& D. Shankweiler (Eds.), Phonological Processes in literacy. Hillsdale, NJ.: Erlbaum.

Green, E. (1997). Guidelines for serving linguistically and culturally diverse young children. Early Childhood Education Journal, 24(3), 147-154. http://dx.doi.org/10.1007/BF02353271

Hatcher, P., Hulme, C., \& Snowling, M. (2004). Explicit phoneme training combined with reading instructions helps young children at risk of reading failure. Journal of Child Psychology and Psychiatry, 45(2), 338-358. http://dx.doi.org/10.1111/j.1469-7610.2004.00225.x

Holm, A., \& Dodd, B. (1996). The effect of first written language on the acquisition of English literacy. Cognition, 59(2), 119-147. http://dx.doi.org/10.1016/0010-0277(95)00691-5

Koda, K. (1990). The use of L1 reading strategies in L2 reading: Effects of L1 orthographic structures on L2 phonological recoding strategies. Studies in Second Language Acquisition, 12(4), 393-410. http://dx.doi.org/10.1017/S0272263100009499

Layton, L., Deeny, K., Upton, G., \& Tall, G. (1966). Researching and promoting phonological awareness in the

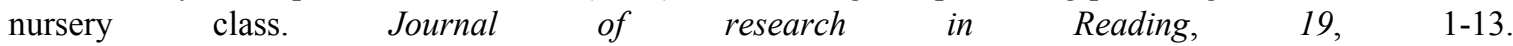
http://dx.doi.org/10.1111/j.1467-9817.1996.tb00082.x

Layton, L., Deeny, K., Upton, G., \& Tall, G. (1998). A pre-school training programme for children with poor phonological awareness: effects on reading and spelling. Journal of Research on Reading, 21(1), 36-52. http://dx.doi.org/10.1111/1467-9817.00041 
Leafstedt, J., Richards, C., \& Gerber, M. (2004). Effectiveness of explicit phonological-awareness instruction for at-risk English learners. Learning Disabilities Research \& Practice, 19, 252-261. http://dx.doi.org/10.1111/j.1540-5826.2004.00110.x

Littleton, K., Wood, C., \& Chera, P. (2006). Interaction with talking books: Phonological awareness affects boy's use of talking books. Journal of Computer Assisted Learning, 22, 382-390. http://dx.doi.org/10.1111/j.1365-2729.2006.00183.x

Lundberg, I., Frost, J., \& Petersen, O. (1988). Effects of an extensive programme for stimulating phonological awareness in pre-school children. Reading Research Quarterly, 23, 263-283. http://dx.doi.org/10.1598/RRQ.23.3.1

MacDonald, J. (2000). Grammaticality Judgments in a second language: Influences of age of acquisition and native language. Applied Psycholinguistics, 21, 395-423. http://dx.doi.org/10.1017/S0142716400003064

National Reading Panel. (2000). Teaching children to read: An evidence-based assessment of the scientific research literature on reading and its implications for reading instruction (NIH Publication No. 00-4769). Washington, DC: U.S. Government Printing Office.

Olofsson, A., \& Niedersoe, J. (1999). Early language development and kindergarten phonological awareness as predictors of reading problems: From 3 to 11 years of age. Journal of Learning Disabilities, 32(5), 464-472. http://dx.doi.org/10.1177/002221949903200512

Perfetti, C. (1985). Reading ability. New York: Oxford University Press.

Perfetti, C. (1991). Representations and awareness in the acquisition of reading competence. In L. Rieben, \& C. Perfetti (Eds.), Learning to read: Basic research and its applications. Hillsdale, NJ: Erlbaum.

Perfetti, C., Beck, I., Bell, L., \& Hughes, C. (1987). Phonemic Knowledge and learning to read are reciprocal. Merrill-Palmer Quarterly, 33, 283-319.

Rubin, H., \& Turner, A. (1989). Linguistic awareness skills in grade one children in a French immersion setting. Reading and Writing: An Interdisciplinary Journal, 1, 73-86. http://dx.doi.org/10.1007/BF00178839

Ryan, A., \& Meara, P. (1991). The case of the invisible vowels: Arabic speakers reading English words. Reading in a foreign language, $7,531-540$.

Share, D. (1995). Phonological recoding and self-teaching: Sine qua non of reading acquisition. Cognition, 55, 151-218. http://dx.doi.org/10.1016/0010-0277(94)00645-2

Siedenberg, M. (1992). Beyond orthographic depth in reading: Equitable division of labor. In R. Frost, \& L. Katz (Eds.), Orthography, phonology, morphology and meaning. Amsterdam: North-Holland. http://dx.doi.org/10.1016/S0166-4115(08)62790-9

Snow, C., Burns, S., \& Griffin, P. (Eds.). (1998). Preventing Reading Difficulties in Young Children. Washington, DC: National Academy Press.

Snowling, M. (1998). Reading development and its difficulties. Educational and Child Psychology, 15, 44-58.

Snowling, M. (2000). Dyslexia (2nd ed.). Oxford: Blackwell Publishing.

Stanovich, K. (1991). Word recognition: Changing perspectives. In R. Barr, M. Kamil, P. Mosenthal, \& P. Pearson (Eds.), Handbook of reading research (Vol. 1). New York: Longman.

Stuart, M. (1995). Prediction and qualitative assessment of five- and six-year-old children's reading: A longitudinal study. British Journal of Educational Psychology, 65, 287-296. http://dx.doi.org/10.1111/j.2044-8279.1995.tb01150.x

Vellutino, F., Fletcher, J., Snowling, M., \& Scanlon, D. (2004). Specific reading disability (dyslexia): What have we learned in the past four decades? Journal of Child Psychology and Psychiatry, 45(1), 2-40. http://dx.doi.org/10.1046/j.0021-9630.2003.00305.x

Vellutino, F., Scanlon, D., \& Tanzman, M. (1994). Components of reading ability. In G. Lyon (Ed.), Frames of reference for the assessment of learning disabilities. Baltimore, MD: Paul H. Brookes.

Verhoeven, L. T. (1994). Transfer in bilingual development: The linguistic interdependence hypothesis revisited. Language Learning, 44, 381-415. http://dx.doi.org/10.1111/j.1467-1770.1994.tb01112.x

Wagner, D. A., Spratt, J. E., \& Ezzaki, A. (1989). Does learning to read in a second language always put the child at a disadvantage? Some counterevidence from Morocco. Applied Psycholinguistics, 10, 31-48. 
http://dx.doi.org/10.1017/S0142716400008407

Wagner, R., Torgesen, J., \& Rashotte, C. (1994). Development of reading-related phonological processing abilities: New evidence of bidirectional causality from a latent variable longitudinal study. Developmental Psychology, 30(1), 73-87. http://dx.doi.org/10.1037/0012-1649.30.1.73

Wanger, D. (1993). Literacy, culture, \& development. New York: Cambridge University Press.

Wood, C. (2005). Beginning readerss' use of "talking books" software can affect their reading strategies. Journal of Research in Reading, 28, 170-182. http://dx.doi.org/10.1111/j.1467-9817.2005.00261.x

Yopp, H. (1988). The validity and reliability of phonemic awareness tests. Reading Research Quarterly, 23, 159-177. http://dx.doi.org/10.2307/747800

\section{Copyrights}

Copyright for this article is retained by the author(s), with first publication rights granted to the journal.

This is an open-access article distributed under the terms and conditions of the Creative Commons Attribution license (http://creativecommons.org/licenses/by/3.0/). 